\title{
LITERATURE STUDY OF MODIFICATION SCALE MEDIA IN LEARNING MEASUREMENT CONCEPTS OF CHILDREN 5-6 YEARS OLD
}

\author{
Siti Rahmawati'), Eka Cahya Maulidiyah²), \\ Universitas Negeri Surabaya ${ }^{1)}$, Universitas Negeri Surabaya ${ }^{2)}$ \\ sitirahmawati16010684051@mhs.unesa.ac.id
}

\begin{abstract}
In the development of the cognitive aspects, one part of it is mathematics. The concept of measurement is one part of mathematics that is close to children. However, it is difficult to teach. Because teaching of measurement concepts in kindergarten is still less varied. So, there is a need for new media that aims to make it easier for children to learn the concept of measurement. This study aims to describe the use of modified weighing media in learning measurement concepts that are referred to at the age of 5-6 years. The measurement concept indicator relates to the child's ability to understand the concept of measuring object weight with the target subject being early childhood with an age range of 5-6 years. The type of research used is literature review, which is using literature reviews in scientific research related to the variables in the study. The analysis technique in research is by analyzing several relevant studies from related articles that are obtained, found, analyzed and concluded. The results of the data analysis concluded that the use of modified weighing media in the learning process of the measurement concept can make it easier for children to learn the concept of measurement.
\end{abstract}

Keywords: modified media scales, measurement concepts

\section{STUDI LITERATUR MEDIA TIMBANGAN MODIFIKASI DALAM PEMBELAJARAN KONSEP PENGUKURAN ANAK USIA 5-6 TAHUN}

\begin{abstract}
Abstrak: Pada perkembangan aspek kognitif salah satu bagian yang ada didalamnya adalah matematika. Konsep pengukuran merupakan salah satu bagian matematika yang dekat dengan anak. Namun, Cukup sulit untuk diajarkan. Hal ini dikarenakan pengajaran konsep pengukuran di TK masih kurang bervariatif. Sehingga, perlu adanya media pembelajaran baru yang bertujuan memberikan kemudahan bagi anak dalam mempelajari konsep pengukuran. Penelitian ini bertujuan untuk mendeskripsikan penggunaan media timbangan modifikasi dalam pembelajaran konsep pengukuran yang ditujukkan pada usia 5-6 tahun. Indikator konsep pengukuran berkaitan dengan kemampuan anak dalam memahami konsep pengukuran berat benda dengan subjek yang dituju merupakan anak usia dini dengan rentang usia 5-6 tahun. Jenis penelitian yang digunakan yaitu literature review yakni menggunakan kajian-kajian pustaka dalam suatu penelitian ilmiah yang berkaitan dengan variabel yang ada dalam penelitian. Teknik analisis dalam peelitian dengan cara menganalisis beberapa penelitian yang relevan dari artikel terkait yang diperoleh, ditemukan, dianalisis dan disimpulkan. Hasil dari analisis data menyimpulkan bahwa penggunaan media timbangan modifikasi dalam proses pembelajaran konsep pengukuran dapat memberikan kemudahan bagi anak dalam mempelajari konsep pengukuran.
\end{abstract}

Kata kunci: media timbangan modifikasi, konsep pengukuran

\section{PENDAHULUAN}

Anak yang merupakan Anugerah yang Tuhan berikan serta tak ternilai harganya. Setiap anak yang lahir didunia ini diberikan pikiran maupun hati yang harus didik serta merawatnya dengan penuh tanggung jawab. Potensi dan kemampuan yang dimiliki oleh setiap anak pun pada dasarnya sama dengan porsinya masing-masing. Namun, itu akan bisa berubah dengan pengaruh yang didapatkan anak dari luar lingkungan disekitarnya. Lingkungan luarlah yang dapat membentuk serta memproses anak menjadi sesuatu kedepannya. 
Merubah maupun menjaga sifat dari setiap individu. Lingkungan juga dapat menjadi pembeda aktualisasi diri anak (Pebrianty, 2014:17) [13].

Pendidikan yang anak dapatkan sebaiknya disesuaikan dengan tahap perkebangan usia anak. Terdapat 2 jenis pendidikan, yakni formal dan non formal yang dapat diberikan pada anak. Pendidikan non formal bisa didapatkan anak melalui interaksinya dengan orang-orang terdekatnya seperti orang tua maupun juga dapat melalui lingkungan sekitarnya, yaitu teman sebaya. Dalam pendidikan formal didapatkan anak melalui jenjang pendidikan yang dapat disesuaikan dengan jenjang usia anak. Untuk anak usia dini terdapat lembaga PAUD yang dapat memberikan pendidikan awal bagi anak dengan menstimulasi seluruh aspek perkembangan pada anak.

Hal yang sama juga diungkapkan oleh Suyadi (2010) [23] yang mengungkapkan bahwa pendidikan anak usia dini pada hakikatnya lebih menekankan pada proses pembelajaran yang lebih terfokus dalam mengembangkan seluruh potensi pada keseluruhan aspek perkembangan anak. Ada berbagai cara yang dapat dilakukan dan juga didukung dengan memfasilitasi secara menyeluruh tumbuh kembang anak. Oleh karenanya, pada jenjang awal yakni Pendidikan Anak Usia Dini (PAUD) dapat menjadi pondasi bagi anak dalam mempelajari berbagai hal dan konsep baru yang digunakan sebagai bekal kelak menempuh pendidikan pada jenjang yang lebih tinggi.

Pendidikan Anak Usia Dini (PAUD) dapat diartikan merupakan sebuah pendidikan awal untuk anak. Jenjang pendidikan ini merupakan jenjang awal anak menerima berbagai macam stimulus yang dapat dengan mudah diserap oleh anak. Sehingga pada masa ini merupakan masa yang sangat tepat untuk mulai diberikannya berbagai macam stimulus yang dapat mendorong tumbuh kembang anak agar mencapai hasil yang maksimal.

Lembaga PAUD yang menjadi lembaga penddikan formal untuk anak usia 4-6 tahun adalah Taman Kanak-kanak (TK). Pada rentang usia inilah berbagai aspek perkembangan pada anak berkembang sangat pesat. Salah satunya adalah aspek perkembangan kognitif. Hal ini didukung dengan pendapat para ahli yang juga mengungkapkan bahwa separuh kecerdasan manusia sudah terbentuk pada 4 tahun awal usia anak atau yang biasa disebut sebagai the golden ages atau usia emas (Iswara, 2013:2) [10]. Oleh karena itu pentingnya diberikan stimulus agar anak pada rentang usia tersebut seluruh kecerdasan yang dimilikinya dapat dikembangkan secara maksimal.

Kecerdasan dan kemampuan berfikir yang dimiliki oleh anak adalah bagian yang penting dan termasuk dalam aspek perkembangan kognitif. Kemampuan berpikir atau kemampuan kognitif mencakup tiga kemampuan, yaitu mempelajari serta memecahkan persoalan, berfikir masuk akal serta berpikir simbolik. Ketiga kemampuan ini merupakan kemampuan dasar dalam aspek perkembangan kognitif yang harus dilatih dan diajarkan sejak dini. Hal ini dikarenkan jika ketiga kemampuan dasar dalam aspek perkembangan kognitif tersebut telah dikuasai dan dimiliki oleh anak sejak dini maka dapat memberikan kemudahan dalam proses berpikir anak pada jenjang selanjutnya.

Matematika penting untuk dipahami sejak dini. Pada kenyataannya matematika merupakan salah satu materi yang cukup sulit untuk dipahami oleh anak. Dapat dikatakan demikian berdasarkan survei The Programme for 
International Student Assessment (PISA) [19] pada tahun 2018 yang mengungkapkan hasil survei yang dilakukan di 79 negara dan Indonesia berada di peringkat 73 dari 79 negara yang disurvei. Hasil yang telah didapatkan dapat disimpukan bahwa Negara Indonesia berada pada level 1a dalam kategori matematika. Hasil ini dapat menjawab serta menunjukkan bahwa kemampuan matematika yang dimiliki oleh anak-anak di Indonesia terbilang masih sangat rendah sehingga perlu dikembangkan lagi.

Hasil survei yang telah dilakukan oleh PISA [19] menunjukkan bahwa mengajrkan berbagai konsep matematika pada anak bukan merupak suatu hal yang mudah untuk dilakukan. Pengenalan matematika pada anak membuthkan proses yang tidak sembarangan serta harus dilakukan dengan tepat agar tujuan yang ingin dicapai dalam pembelajaran dapat sesuai dengan apa yang diharapkan. Pembelajaran matematika pada anak membutuhkan aturan yang mengacu pada standar yang berlaku. Ada beberapa hal yang harus lebih diperhatikan dalam mengajarkan konsep matematika pada anak yaitu, pada penyampaian materi serta cara yang digunakan dalam penyampaian materi harus benar.

Memperhatikan aturan yang berlaku dalam menyampaikan pembelajaran matematika pada anak dilakukan karena pemberian materi matematika pada awal pengenalan yang tidak sesuai dengan konsep akan mengakibatkan misconcept. Hal ini akan sangat berdampak buruk pada jenjang selanjutnya, yang nantinya akan berpengaruh pada cara berpikir anak pada tingkat yang lebih tinggi. Sedangkan untuk cara yang digunakan dalam penyajian materi yang tidak sesuai tahap perkembangan usia anak juga akan mengakibatkan kejenuhan, kelelahan, hingga phobia pada matematika (Musrikah, 2017) [11]. Oleh karena itu perlu adanya penyampaian materi dengan cara yang tepat agar mewujudkan pembelajaran matematika yang ideal.

Terdapat beberapa konsep standart dalam matematika yang harus dikuasai anak sejak dini. Menurut (The National Council Teachers of Matematics, 2000) [24] salah satunya adalah konsep pengukuran. Dalam Permendikbud No. 137 Tahun 2014 [14] Tentang Standar Nasional Pendidikan Anak Usia Dini menjelaskan bahwa Standar Tingkat Pencapaian Perkembangan Anak (STPPA) dalam lingkup aspek kognitif berfikir logis anak usia 5-6 tahun diantaranya adalah: (1) Mengenal perbedaan berdasarkan ukuran: "lebih dari"; "kurang dari"; dan "paling/ter", (2) Mengklasifikasikan benda berdasarkan warna, bentuk, dan ukuran (3 variasi), (3) Dapat mengurutkan benda berdasarkan ukuran dari paling kecil ke paling besar atau sebaliknya.

Didukung juga dengan pernyataan Jean Piaget yang mengungkapkan bahwa anak usia 4-6 tahun sudah berada pada tahap pra operasional. Pada tahap ini anak akan sudah menggunakan logika pada tempatnya artinya, anak sudah dapat memahami mengenai suatu konsep sederhana yang diajarkan (Santrock, 2007: 48-49) [18].

\section{The Common Core State} Standart for Mathematics juga mengemukakan harapannya agar anak-anak dapat diajarkan mengenai konsep pengukuran sedini mungkin. Hal ini bertujuan karena pemberian bekal pembelajaran konsep pengukuran pada anak sejak usia dini dapat berpengaruh pada kehidupan keseharian anak. Hal ini didasarkan pada penggunaan konsep pengukuran yang disadari maupun tidak 
penerapnnya sangat tersa pada keseharian anak. Kegiatan keseharian anak seperti, pengukuran berat badan, saat pengukuran tinggi badan, membedakan panas atau dingin, mengungkapkan jarak, dan lain sebagainya (Reys, 2012: 348) [15].

Melihat begitu pentingnya pembelajaran mengenai konsep pengukuran diajarkan sejak dini pada anak maka perlu adanya sebuah proses pembelajaran konsep pengukuran yang lebih menyenangkan bagi anak. Pembelajaran yang dapat memberikan susaana yang yang menyenangkan pada anak dpat memberikan pengaruh yang positif juga pada anak sat menerima materi pembelajaran tersebut. Proses belajar pengukuran yang dilakukan sekarang ini masih terbilang kurang menarik. Harusnya proses belajar dilakukan dengan lebih menarik contohnya dapat melalui sebuah permainan ataupun menggunakan berbagai media penunjang lainnya dalam proses pembelajaran akan lebih terkesan menarik bagi anak.

Media merupakan salah upaya dalam berkomunikasi serta sumber informasi yang mengacu pada segala hal yang memuat informasi dari asalnya serta yang menerima. Media dalam juga dapat diartikan sebagai bahan atau peristiwa yang dapat membentuk sebuah keadaan untuk memperoleh sebuah ilmu yang baru (Arsyad, 2013:3) [1]. Penggunaan media dalam bentuk yang lebih konkret dan sesuai dengan konsep yang diajarkan sangatlah dibutuhkan anak. Hal ini dimaksudkan agar pemahaman mengenai suatu konsep dapat diterima baik oleh anak dalam hal ini pembelajaran mengenai konsep pengukuran.

Hal ini didukung oleh teori Jean Piaget (dalam Santrock, 2007: 48-49) [18] yang menyatakan tahap praoperasional konkret (4-5 tahun). Dalam tahap ini dapat dikatakan tahap persiapan sebelum anak menuju ke arah pengorganisasian yang lebih konkret dengan berpikir intuitif. Yang mana jika diartikan dalam tahap ini anak mampu mampu dalam mempertimbangkan hal-hal yang berkaitan dengan pembahasan mengenai ukuran dan bentuk benda berdasarkan benda yang disekitarnya sesuai dengan persepsinya sendiri. Berdasarkan hal tersebut penggunaan media yang lebih konkret serta berkaitan langsung dengan konsep yang diajarkan secara tidak langsung memberrikan kemudahan bagi anak dalam memahami berbagai konsep yang sedang dipelajari.

Berdasarkan pada apa yang telah dijabarkan sebelumnya mengembangkan berbagai konsep matematika tidak dapat dianggap sebagai hal yang mudah. Perlu adnya seebuah inovasi dan kreativitas yang dapat mengemas proses pembelajran yang tadinya dianggap sebagai sesuatu yang menakutnya menjadi sesuatu hal yang menyenangkan untuk dipelajari. Dalam mengubah pandangan dan perspektif anak untuk melihat betapa menyenangkannya pembelajaaran dalam matematika itu dilakukan maka guru sebagi pendidik perlu melakukan sebuah inovasi dalam proses pembelajaran yang telah dilakukan. Tujuannya adalah agar membuat suasana menjadi kondusif dan menyenangkan sehingga proses pembelajran dapat terlaksana secara maksimal.

Menurut teori Jean Piaget (dalam Santrock, 2007: 48-49) [18] perkembangan kognitif pada anak dibagi mejadi empat tahap yaitu, tahap sensorimotor, tahap pra operasional konkret, tahap operasional konkret dan tahap formal. Pada tahap pra operasional konkret yang termasuk pada tahap ini adalah anak dengan rentang usia 4-6 tahun. Pada tahap ini anak masih 
dalam tahap persiapan dimana anak aka nada tahap setelah yaitu menuju tahap kearah pengorganisasian yang lebih konkret dengan berpikir intuitif. Bahwa anak pada tahap ini akan mampu mempertimbangan berbagai benda yang ada disekitarnya berdasarkan pada interpretasi pengalamannya sendiri. Sehingga perlu adanya sebuah media konkret yang dapat membantu anak dalam berpikir lebih konkret.

Berdasarkan pada pernyataanpernyataan diatas maka dalam pembelajaran konsep pengukuran yang cukup sulit dipahami oleh anak memerlukan sebuah media pembelajaran yang dapat menndukung proses pembelajaran konsep pengukuran agar dapat lebih mudah untuk dipahami

oleh anak. Dilihat juga pada kegunaan memahami ukuran merupakan suatu yang bermanfaat digunakan pada setiap keseharian anak mengakibatkan pemahaman anak sejak dini mengenai konsep peengukuran juga perlu dilakukan. Hal ini menghindari ketidakmampuan anak nantinya dalam mempelajari konsep lain pada matematika yang lebih sulit pada jenjang yang lebih tinggi.

Sebagai salah satu alternatif yang dapat digunakan guru dalam mengajarkan konsep pengukuran agar terasa lebih efektif serta menyenangkan bagi anak adalah melalui sebuah media pembelajaran yang inovatif. Media timbangan modifikasi hadir sebagai media pendukung guru dalam proses pembelajaran konsep pengukuran. Media timbangan modifikasi yang memiliki desain inovatif dengan berdasarkan pada kriteria pemilihan media yang cocok bagi memungkinkan media timbangan modifikasi ini akan sangat cocok digunakan oleh guru. Perubahan desain yang lebih menarik serta penambahan beberapa fitur yang dapat memberikan fungsi tambahan

bagi guru membuat media dirasa lebih efektif dan sangat menarik.

Pemilihan media timbangan modifikasi ini dalam alternative memecahkan permasalahan didasarkan pada beberapa penelitian yang telah lebih dulu mengujicobakan media timbangan jika digunakan dalam proses pembelajaran konsep pengukuran yang bertujuan untuk meningkatkan pemahaman anak akan konsep pengukuran pada matematika. Penelitian Indarwati (2016) [9] menghasilkan data peningkatan yang terjadi pada pemahaman konsep pengukuran setelah menggunakan media timbangan dalam belajar. Dari penelitian ini dapat disimpulakan bahwa adanya keterkaitan yang cukup tinggi antara penggunaan media pembelajaran berupa timbangan dengan pemahaman anak mengenai konsep pengukuran dalam proses pembelajaran konsep pengukuran.

Dari uraian di atas maka dapat disimpulkan bahwa terdapat beberapa faktor terjadinya permasalahan yang terkait dengan permasalahan yang telah dijabarkan diatas. Salah faktor yang paling menonjol adalah kurang bervariatifnya media yang digunakan digunakan pendidik menyebabkan proses pembelajaran terkesan mnoton dan kurang menyenangkan bagi anak. Faktor lainnnya adalah ketidaksesuaian antara media yang digunakan guru dalam proses pembelajaran konsep pengukuran mengakibatkan kebingungan pada anak sehingga berpengaruh pada daya tanggap anak yang kurang tanggap dalam memproses informasi yang diberikan oleh guru. Hal-hal inilah yang menjadi faktor penyebab anak kesusahan mempelajari konsep pengukuran.

Oleh karena itu, media timbangan modifikasi dapat menjadi 
sarana yang ideal untuki menjawab permasalahan mengenai kurang variatifnya media pembelajaran yang digunakan pendidik. Melalui media timbangan modifikasi dalam proses pembelajaran konsep pengukuran akan tercipta suasana lingkungan belajar baru serta berkesan bagi anak, sehingga dapat memicu anak untuk berpikir lebih kreatif dan kritis.

Dari penjabaran yang telah diurakan pada latar belakang sebelumnya maka dapat dipaparkan bahwa penelitian ini bertujuan untuk mendeskripsikan mengenai penggunaan media timbangan modifikasi dalam pembelajaran konsep pengukuran pada anak usia 5-6 tahun. Peneliti berharap penelitian ini dapat menjadi sarana guru dalam mengajarkan konsep pengukuran dengan cara yang lebih menyenangkan bagi anak. Salah satunya dengan penggunaan media konkret berupa timbangan modifikasi ini dalam proses pembelajaran.

\section{METODE PENELITIAN}

Jenis penelitian yang digunakan dalam penelitian ini adalah literature review. Jenis penelitian literature review dapat diartikan sebagai sebuah penelitian yang menggunakan kajiankajian pustaka dalam suatu penelitian ilmiah yang berkaitan dengan variabel yang ada pada penelitian ini. Menurut Sukmadinata (2009: 52) [22] dalam penelitian ini pengumpulan data pustaka akan lebih berkaitan dengan apa yang diperoleh dari berbagai informasi yang didapatkan dari sumber kepustakaan. Penelitian ini akan lebih berfokus pada pengumpulan berbagai literatur dengan mencari informasi data pustaka dari berbagai jurnal ilmiah online.

Berbagai literatur maupun informasi sumber yang digunakan berasal dari data sekunder yaitu, informasi yang didapatkan merupakan hasil penelitian relevan terdahulu.

Adapun teknik pengumpulan data sekunder diperoleh dari:

1. Proses pemilihan artikel penelitian yang terkait dengan media pembelajaran lainnya, pembelajaran konsep pengukuran dan penelitian yang menggunakan metode kuantitatif, kualitatif dan pengembangan. Penemuan hasil penelitian yang memenuhi kategori akan masuk pada tahap analisis lebih lanjut.

2. Mengidentifikasi artikel dilakukan dengan cara membuat kategori yang lebih sistematis. Artikel yang masuk dalam kategori ditunjukkan pada tabel 1.

Tabel 1. Kategori Sumber Data

\begin{tabular}{lc}
\hline \multicolumn{1}{c}{ Kategori } & Total \\
\hline Media pembelajaran & 5 \\
Media pembelajaran & 2 \\
modifikasi & \\
Kemampuan kognitif & 1 \\
Pembelajaran matematika & 2 \\
$\begin{array}{l}\text { Pembelajaran konsep } \\
\text { pengukuran }\end{array}$ & 3 \\
\hline
\end{tabular}

3. Meninjau dengan menganalisis lebih dalam yang dilakukan dengan menyeleksi data-data yang telah ditemukan sebelumnya. Penyeleksian data ini ditujukan untuk memilah artikel-artikel yang akan dibutuhkan dan digunakan sebagai sumber penelitian untuk dianalisis dan dibahas.

Pengumpulan data dari literature review akan dilakukan secara manual dengan cara mengekstraksi data yang telah didapatkan kemudian untuk beberapa data yang sesuai dengan kriteria limitasi berdasarkan kata kunci yang telah dipaparkan sebelumnya. Ditemukan puluhan jurnal yang memiliki kaitan dengan beberapa kata kunci yang telah ditentukan. Dari puluhan jurnal tersebut akan dipilah lagi dengan cara discreening berdasarkan full text. Sehingga 
ditemukan artikel maupun jurnal full text yang relevan dengan topik yang akan dibahas dalam penelitian literature review ini sebanyak 13 artikel.

Langkah selanjutnya setelah menemukan 13 artikel yang sesuai dengan topik yang akan dibahas dalam penelitian. Selanjutnya untuk dapat lebih memperjelas analisis abstrak dan full text jurnal perlu adanya review yang lebih mendalam terhadap 13 jurnal. Proses ini akan dilakukan dengan membaca kemudian mencermati isi dari jurnal-jurnal tersebut. Ringkasan dari jurnal tersebut kemudian dilakukan analisis terhadap isi jurnal-jurnal tersebut. Menggunakan metode analisis isi ini meliputi, tujuan penelitian dan hasil atau temuan penelitian. Semua data yang telah terkumpul akan dicari persamaan maupun perbedaan dengan penelitian ini. Selanjutnya semua data tersebut yang selaras dengan topik yang dibahas dalam penelitian ini akan dibahas dalam bab pembahasan dan selanjutnya akan digunakan untuk menarik kesimpulan dari penelitian ini.

\section{HASIL DAN PEMBAHASAN}

Hasil yang didapatkan berdasarkan dari pengumpulan serta review dari berbagai literature yang telah ditemukan dan sesuai membahas mengenai topik permasalahan yang sama didapatkan hasil dari beberapa istilah yang telah dipaparkan sebelumnya. Hasil ini mencakup penjelasan serta uraian dari beberapa istilah penting yang dimaksud diantaranya penjelasan mengenai permasalahan yang berkaitan dengan pembelajaran konsep pengukuran serta dampak yang ditimbulkan pada kemampuan anak yang kurang dalam pemahaman konsep pengukuran.

Pada penelitian ini menggunakan media timbangan modifikasi sebagai variabel bebas. Berdasarkan pada pencarian dari berbagai jurnal ilmiah online, peneliti tidak menemukan kesamaan variabel yang sama dengan variabel penelitian ini. Sehingga peneliti menggunakan kata kunci yang berbeda namun, masih memiliki kesamaan tujuan dalam proses pembelajaran matematika yang merujuk pada pembelajaran konsep pengukuran anak usia dini.

Pencarian dilakukan dengan kata kunci media pembelajaran maupun dengan berbagai metode lain dalam mengajarkan konsep pengukuran pada anak usia dini. Berbagai macam media dalam pembelajaran maupun nama media lain dalam proses pembelajaran konsep pengukuran seperti media neraca, media timbangan dan berbagai macam permaianan dan metode. Alasan ini mengacu pada fungsi dan kegunaan media maupaun permaianan dan metode tersebut yang memiliki kesamaan yaitu berhubungan dengan matematika terutama pada pembelajaran konsep pengukuran.

Sedangkan variabel terikat pada penelitiannya ini adalah pembelajaran konsep pengukuran pada anak usia 56 tahun. Penelitian relevan menggunakan kata kunci kemampuan kognitif, pembelajaran matematika, maupun pembelajaran konsep pengukuran pada anak usia 5-6 tahun. Hal ini disebabkan penelitian terdahulu yang membahas fokus pada topik kosep pengukuran masih jarang ditemukan sehingga pencarian akan lebih umum lagi dengan mengarah pada kemampuan kognitif yang nantinya akan bersinambungan dengan pembelajaran matematika dan berlanjut ke arah yang lebih spesifik lagi menunju pembelajaran konsep pengukuran pada anak usia 5-6 tahun.

Penggunaan media timbangan modfifikasi dalam proses pembelajaran konsep pengukuran pada anak usia 5-6 tahun tidak ditemukan penelitian yang sama. Oleh karena itu pengambilan data akan dilakukan dengan menggunakan 
penelitian relevan yang berkaitan dengan judul penelitian ini yaitu media timbangan modifikasi dalam proses pembelajaran konsep pengukuran.

Dari berbagai penelitian yang telah direview dan mendukung data pada penelitian ini. Dapat diuraikan bahwa permasalahan umum yang terjadi dalam hal ini dikaitkan dengan berbagai jurnal yang telah direview dan dianalisi sebelumnya, adalah kurang adanya variasi yang dilakukan guru dalam penggunaan media sebagai salah satu sarana pendukung dalam mengajrkan berbagai konsep matematika pada anak.

Hal yang sama juga didapatkan pada penelitian Hayuningtya (2014) [6] dalam penelitian ini juga mengungkapkan peningkatan pemahaman konsep matematika pada anak yang naik secara cukup signifikan setelah menggunakan media dengan pemanfaatan sumber belajar menggunakan limbah kardusuntuk. Peningkatan matematika permulaan anak ini terjadi setelah diberikannya suatu kegiatan yang lebih menarik bagi anak namun masih dapat mengandung unsur pembelajaran didalamnya.

Pada penelitian Desyarani dan Ningrum (2019) [4] juga mengungkapkan hasil positif dalam usaha guru dalam memberikan sebuah media menarik yang diharapkan dengan ini terjadi peningkatan pada kemampuan yang dimiliki anak dalam mengenal lambang bilangan 1-20. Hasil positif ini didapatkan dengan pengembangan sebuah alternatif baru dalam penggunaan media pembelajaran. Media ini berupa media numeric stick yang ditujukan dalam menyelesaikan permasalahan mengenai kemampuan anak dalam mengenal lambang bilangan 1-20 yang dinilai masih rendah.

Pada matematika terdapat berbagai konsep dasar didalamnya yang harus diperkenalkan pada anak sejak dini. Seperti yang diungkapkan dalam penelitian Novikasari (2016) [12]
Matematika Dalam Program Pendidikan Anak Usia Dini (PAUD) yang menyatakan bahwa matematika hendaknya dapat diajarkan pada anak sesuai dengan tahapan perkembangan kognitif pada anak. Porsi pemberian materi yang pas pada anak akan dapat diserap dengan baik. Sehingga tujuan yang ingin dicapai pun dapat tercapai secara maksimal.

Dalam mengajarkan berbagai konsep yang ada pada matemataika perlu adanya ketentuan yang sesuai antara apa yang ingin disampaian dengan media sebagai alat perantara yang mendukung dalam proses pembelajaran. Pada penelitian Boeriswati dkk (2019) [2] dengan judul mengungakan hasil bahwa dalam penerapannya media pembelajaran matematika harus mempunyai komponen kelengkapan (1) berorientasi pada STEAM, (2) memperhatikan saran-saran dari hasil penelitian bidang neuroscience dalam pembelajaran matematika, dan dalam m-learning, (3) mendorong pemberdayaan keterampilan digital untuk melaksanakan literasi, (4) mendorong kolaborasi virtual antara guru dengan anak maupun anak dengan teman sebaya, memberdayakan VR, (6) dilengkapi dengan sistem ujian, (7) akuntabel, (8) aman, (9) memungkinkan pengambilan keputusan yang tepat berdasarkan analisa pembelajaran berbantuan kecerdasan buatan, (10) dapat dikembangkan dengan cepat.

Permasalahan yang sama mengenai rendahnya kemampuan matematika anak juga terlihat pada salah satu konsep matematika yaitu, konsep pengukuran. Dari permasalahan ini mengakibatkan rendahnya kemampuan yang dimiliki anak dalam pemahaman berbagai konsep matematika. Seperti yang diungkapkan dalam penelitian Sa'ida dkk (2017) [17] dalam penelitain ini 
juga membahas mengenai latar belakang yang sama yaitu, kesulitan yang dihadapi anak dalam memahami berbagai konsep baru pada matematika. Terutama pada konsep pengukuran yang dapat dikategorikan dalam konsep yang cukup abstrak untuk apat dipahami oleh anak.

Selain itu juga terdapat permasalahan lain yang terjadi seputar proses pembelajaran matematika pada anak. Pada penelitian Rosita dan Khotimah (2017) [16] menjelaskan bahwa penelitian ini dilakukan dengan tujuan dapat memberikan alternatif baru bagi guru dalam mengajarkan konsepkonsep matematika salah satunya konsep bilangan. Dengan pemilihan metode yang dipilih adalah analisis deskriptif penggunaan sampel menggunakan sampel kelompok A. Hasil dari penelitian ini dapat dideskripsikan bahwa penggunaan sebuah media dalam mengajarkan berbagai konsep matematika sangat dibutuhkan anak agar dapat memahami konsep tersebut dengan lebih mudah.

Oleh karenanya perlu ada sebuah perubahan suasana dalam proses pembelajaran konsep pengukuran agar lebih menyenangkan dan tidak menimbulkan kebosanan bagi anak. Ada berbagai cara yang dapat dilakukan guru dalam mengubah poses pembelajaran agar lebih menyenangkan bagi anak. Dalam beberapa penelitian terdahulu juga mengungkapkan beberpa pilihan yang dapat dilakukan guru dalam menjadikan suasana saat proses pembelajaran dapat berlangsung lebih menyenangkan.

Pada penelitian Septikasari (2015) [20] mengungkapkan bahwa kurangnya pemahaman anak dalam memahami konsep pengukuran juga dapat disebabkan oleh penggunaan media yang tidak sesuai. Dalam penelitian ini memberikan sebuah alternatif yang dapat dilakukan guru untuk mengajarkan konsep pengukuran pada anak kelompok
A yaitu dengan kegiatan bermain pasir menggunakan neraca. Hasil yang didapatkan bahwa terjadi peningkatan kemampuan pemahaman konsep pengukuran mulai dari pra tindakan, siklus I, dan siklus II.

Banyak sekali cara yang dapat digunakan dalam mengajarkan konsep pengukuran. Seperti, variasi metode, permainan, maupun media pembelajaran konsep pengukuran dapat dilakukan melalui penggunaan media audiovisual. Pada penelitian Setyowahyudi dan Suyanto (2018) [21] dengan judul The Impact of Audiovisual Media Towards Ability on Counting, Measurement, and Geometric mendapatkan hasil dari penelitian tersebut bahwa pengaruh penggunaan media sangat berdampak pada kemampuan anak dalam pembelajaran konsep pengukuran. Berbagai variasi yang dapat digunakan guru dalam menyampaikan pembelajaran mengenai konsep pengukuran akan memberikan kesan yang menyenangkan dan tidak membosankan bagi anak, sehingga pemahaman anak mengenai konsep pengukuran juga akan dapat dengan mudah dipahami oleh anak.

Dari berbagai variasi metode, permaian, dan berbagai media lain yang daopat digunakan untuk mengajarkan konsep pengukuran. Media pembelajaran merupakan salah satu yang sesuai jika digunakan dalam mengajarkan konsep pengukuran. Dapat dikatakan demikian didasarkan pada penggunaan media pembelajaran memiliki hubungan erat dengan pembelajaran konsep pengukuran pada anak. Dari beberapa hasil penelitian yang dikaji dan dianalisis mengungkapkan adanya hubungan positif antara penggunaan media pembelajaran terhadap kemampuan memahami konsep pengukuran pada anak usia 5-6 tahun. Dibuktikan oleh pnelitian Fury dan Sasmiati (2018) [5] 
dalam penelitian ini membahas mengenai keterkaitani penggunaan mediaidengan pemahamani konsep pengukuran.

Ada berbagai macam jenis media yang dapat digunakan dalam mengajarkan konsep pengukuran. Media buku bergambar misalnya yang juga merupakan salah satu pilihan media yang dapat digunakan. Padai penelitian Heuvel-Panhuizen and Elia (2011) [7] yang berjudul 'Kindergartners' Performance in Length Measurement and The Effect Of Picture Book Reading" menghasilkan data bahwa terdapat pengaruh penggunaan media buku bergambar dalam pembelajaran konsep pengukuran panjang. Subjek penelitian terdiri dari anak dengan rentang usia 4-6 tahun.

Namun, jika kita membahas mengenai konsep pengukuran. Media yang kaitannya dekat dengan konsep pengukuran yaitu, media timbangan. Penggunaan media timbangan dalam mengajarkan konsep pengukuran dirasa sangat sesuai penggunaannya. Namun, perlu diingat juga dalam penggunaan media pembelajaran agar dapat mendukung proses pembelajaran harus memenuhi kriteria media pembelajaran yangi baiki bagi anak usia dini Depdiknas (2006: 3) [3].

Pada penelitian Septikasari (2015) [20] mengungkapkan bahwa penggunaan media timbangan dalam pembelajaran konsep pengukuran berdampak sangat positif dan menunjukkan adanya peningkatan terhadap kemampuan anak dalam memahami konsep pengukuran.

Dari penelitian tersebut didapatkan data bahwa media timbaagan modifikasi merupakan salah satunya media yang sesuai digunakan pada anak. Hasil dari penelitian-penelitian terdahulu yang membahas mengenai topik media timbangan mengungkapkan bahwa penggunaan media timbangan dalam pembelajaran konsep pengukuran berdampak sangat positif dan menunjukkan adanya peningkatan terhadap kemampuan anak dalam memahami konsep pengukuran.

Hal ini dibuktikan dengan beberapa penelitian yang telah melihat efektivitas dari penggunaan media timbangan dalam meningkatkan kemampuan pemahaman konsep pengukuran anak pada saat pembelajaran konsep pengukuran. Hal yang selaras juga diungkapkan dalam penelitian Indarwati (2016) menyatakan hasil dengan mendeskripsikan mengenai perbedaan yang signifikan pada kemampuan konsep pengukuran anak setelah dan sebelum menggunakan media timbangan manipulatif.

Berbagai hasil, pembahasan dan kesimpulan yang telah ditemukan serta diperoleh dari berbagai data yang factual berdasarkan penelitianpenelitian yang sudah lalu namun masih relevan dengan penelitian ini membuktikan bahwa begitu berkaitannya penggunaan media pembelajaran dalam mennujang proses pembelajaran yang berlangsung. Dampak yang ditimbukanpun sangat positif dengan adanya penggunaan media timbangan dalam proses pembelajaran konsep pengukuran. Meskipun begitu masih ada kelemahan dan kekurangan dari media timbangan modifikasi ini.

Kelemahamnya terletak pada media yang masih belom diuji cobakan membuat media timbangab modifikai ini masih rentan akan kesalahan saat proses penggunaannya. Namun, kelebihannya terletak pada kebaharuan yang muncul saat penggunaan emedia timbangan modifikasi ini memberikan kesan kemenarikan yang tinggi bagi anak. Sehingga dimungkinkan untuk anak dapat fokus dalam proses pembelajaran dan dapat menyerap 
konsep pengukuran yang diajarkan dengan baik.

\section{SIMPULAN}

Penelitian ini mengkaji dengan mendeskripsikan topik mengenai media timbangan modifikasi dalam pembelajaran konsep pengukuran anak usia 5-6 tahun. Media timbangan modififikasi merupakan sebuah timbangan yang memiliki fungsi serta tujuan yang sama dalam pembelajaran dengan media timbangan pada umumnya yaitu untuk mengajarkan konsep pengukuran berta. Namun, pada media timbangan modifikasi ini peneliti melakukan mdifikasi pada desain dari media itu sendiri. Dengan penambahan aksen tempat penyimpanan alat ukur lainnya serta pemberian warna-warna yang menarik bagi anak membuat media ini terkesan lebih menyenangkan jika digunakan pendidik dalam mengajarkan konsep pengukuran.

Didapatkan hasil dari berbagai penelitian-penelitian relevan yang telah dipilih melalui proses screening serta sudah direview untuk mengetahui keterkaitannya dengan penelitian ini sehinggga didapatkan hasil bahwa media timbangan modifikasi dapati menjadi alternatif dalam pembelajaran konsep pengukuran. Kemudahan yang ditawarkan media timbangan modifikasi pada anak dalam mempelajari berbagai konsep pengukuran yang abstrak, diharapkan penggunaan media timbangan modifikasi dapat menjadi salah satu media pembelajaran yang digunakan oleh pendidik dalam mengajarkan konsep pengukuran pada anak usia 5-6 tahun.

Berdasarkan hasil penelitian literature review dengan judul Studi Literatur Media Timbangan Modifikasi Dalam Pembelajaran Konsep Pengukuran, maka diberikan beberapa saran sebagai berikut :

1. Bagi Guru

Diharapkan dapat digunakan sebagai pedoman dalam penerapan pokok bahasan belajar mengajar yang diterapkan di kelas dengan menggunakan media timbangan modifikasi sebagai alternatif media dalam pembelajaran konsep pengukuran, serta dapat menambah pengetahuan bahwa menggunakan media timbangan modifikasi mampu memberikan dampak positif.

2. Bagi Sekolah

Diharapkan mampu menjadi referensi maupun alternative media yang lebih menarik untuk dapat diaplikasikan di sekolah. Sehingga dalam proses pembelajaran akan terkesan menyenangkan dalam mengaplikasikan media yang bagus, baik dan lebih menarik serta menyenangkan untuk anak dalam kegiatan belajar mengajar di kelas.

3. Bagi Peneliti selanjutnya

Diharapkan dapat diguakan sebagai ide baru dalam menciptakan sebuah media yang lebih kreatif dan inovatif. Dimaksudkan agar bisa memaksimalkan perkembangan kognitif dalam berhitung permulaan anak usia 5-6 tahun. Selain itu juga saran bagi peneliti selanjutnya dapat menerusan penelitian ini ke dalam bentuk penelitian eksperimen agar dapat menerapkan media timbangan modifikasi ini ke lapangan yang sesungguhnya.

\section{DAFTAR PUSTAKA}

[1] Arsyad, A. (2013). Media Pembelajaran. Jakarta: Kharisma Putra Utama Offset.

[2] Boeriswati, Endry dkk. (2019). Media Pembelajaran Matematika Menyongsong Industry 4.0 : Tinjauan Literatur Sistematis untuk Analisis Kebutuhan. Artikel. Research Gate, (Online), (https://www.researchgate.net/pub lication/330506130, diakses pada 17 April 2020) 
[3] Departemen Pendidikan Nasional. (2006). Standarisasi Alat Peraga/Bermain di Taman KanakKanak. Jakarta: Direktorat Pembinaan Taman Kanak-Kanak dan Sekolah Dasar.

[4] Desyarani, Ayu dan Ningrum, Mallevi Agustin. (2019). Pengembangan Media Numeric Stick dalam Meningkatkan Kemampuan Mengenal Lambang Bilangan 1-20 Anak Usia 5-6 Tahun. Jurnal PAUD Teratai. Volume 08 Nomor 02, (Online), (https://jurnalmahasiswa.unesa.ac.id, diakses pada 15 Juni 2020).

[5] Fury, Destila Permata dan Sasmiati. (2018). Hubungan antara Penggunaan Media Pembelajaran dengan Pemahaman Konsep Ukuran pada Anak Usia 5-6 Tahun di PAUD Cut Mutia Bandar Lampung. Skripsi. Fakultas Keguruan dan Ilmu Pendidikan Universitas Lampung Bandar Lampung.

[6] Hayuningtya, Hesti. (2014). Pemanfaatan Sumber Belajar Dengan Limbah Kardus untuk Mengembangkan Konsep Matematika Permulaan Anak Usia56 Tahun (Studi Eksperimen Di TK Taman Indria Semarang). Early Childhood Education Papers (Belia).

[7] Heuvel-Panhuizen, Marja Van den and Elia, Iliada. (2011). Kindergartners' Performance in Length Measurement and The Effect of Picture Book Reading. ZDM Mathematics Education. Vol. 43: hal 621-635.

[8] Ibda, Fatimah. (2015). Perkembangan Kognitif: Teori Jean Piaget. INTELEKTUALITA. Volume 3, Nomor 1.
[9] Indarwati, Ima. (2016). Efektivitas Penggunaan Media Timbangan Manipulatif Terhadap Kemampuan Konsep Pengukuran pada Anak Kelompok B di TK Negeri Pembina Sragen. Skripsi Pada Jurusan PGPAUD Universitas Negeri Semarang.

[10] Iswara, P. (2013). Studi Tentang Kegiatan Bernyanyi pada Pembelajaran "Calistung" untuk Anak Usia Dini di TK Sekolah Alam Bandung. Jurnal SwaraAntologi Jurusan Pendidikan Seni Musik UPI. Vol.1 (3): hal. 1-9.

[11] Musrikah. (2017). Pengajaran Matematika pada Anak Usia Dini. Martabat: Jurnal Perempuan dan Anak. Vol. 1 No. 1.

[12] Novikasari, Ifada. (2016). Matematika dalam Program Pendidikan Anak Usia Dini (PAUD). Bunayya: Jurnal Pendidikan Anak. Vol. 02 (1): hal 1-16.

[13] Pebrianty, Kiki Dwi dkk. (2014). Pengenalan Matematika Permulaan dengan Konsep Pengukuran pada Anak Usia 5-6 Tahun di TK Kartika XVII-17 Sintang. Jurnal Pendidikan dan Pembelajaran. Volume 3 (5): hal. 1-12.

[14] Peraturan Menteri Pendidikan dan Kebudayaan Republik Indonesia Nomor 137 tahun 2014 tentang Standar Nasional Pendidikan Anak Usia Dini. (2014). Jakarta: Departemen Pendidikan Nasional.

[15] Reys, Robert, dkk. (2012). Helping Children Learn Mathematics. United States of Amerika: John Wiley \& Sons, Inc. 
[16] Rosita, Rengga dan Khotimah, Nurul. (2017). Peningkatan Kemampuan Mengenal Konsep Bilangan 1-10 Melalui Media Kereta Bernomor Pada Anak Kelompok A di TK Dahlia Desa Jenisgelaran Bareng Jombang. Jurnal PAUD Teratai. Volume 06 Nomor 03, (Online), (https://jurnalmahasiswa.unesa.ac.id, diakses pada 15 Juni 2020).

[17] Sa'ida, Naili dkk. 2017. Problem Based Learning Sebagai Upaya Pengenalan Konsep Pengukuran Pada Anak Usia Dini. PEDAGOGI: Jurnal Anak Usia Dini dan Pendidikan Anak Usia Dini. Volume 3 Nomor 3c.

[18] Santrock, John W. 2007. Perkembangan Anak. Jakarta: Penerbit Erlangga.

[19] Schleicher, Andreas. 2018. PISA 2018: Insights and Interpretations. OECD: Secretary-General.

[20] Septikasari, Friska Risky. 2015. Peningkatan Pemahaman Konsep Ukuran Melalui Kegiatan Bermain Pasir Menggunakan Neraca Sederhana pada Kelompok A Ra Nurul Ummah Karangduwet, Mojayan, Klaten Tengah. Skripsi pada Jurusan Pendidikan Pra Sekolah dan Sekolah Dasar Fakultas Ilmu Pendidikan Universitas Negeri Yogyakarta.

[21] Setyowahyudi, Rendy dan Suyanto, Slamet. 2018. The Impact of Audiovisual Media Towards Ability on Counting, Measurement, and Geometric. ICSTI 2018, Yogyakarta, Indonesia.

[22] Sukmadinata, Nana Syaodih. 2009. Metode Penelitian Pendidikan. Bandung: Remaja Rosdakarya.
[23] Suyadi. 2010. Psikologi Belajar PAUD. Yogyakarta: PT Bintang Pustaka Abadi.

[24] The National Council Teachers of Matematics. 2000. Principles and Standards for School Mathematics. Virginia: Reston. 